\title{
Drosophila as a Potential Model for Ocular Tumors
}

\author{
Daimark Bennett $^{a} \quad$ Ekaterina Lyulcheva ${ }^{a, b} \quad$ Neville Cobbe $^{a}$ \\ ${ }^{a}$ Institute of Integrative Biology, University of Liverpool, Liverpool, and b North Western \\ Deanery, Salford Royal NHS Foundation Trust, Salford, UK
}

\section{Key Words}

Ocular oncology $\cdot$ Retinoblastoma $\cdot$ Uveal melanoma $\cdot$ Drosophila $\cdot$ Cancer model .

Ocular cancer

\begin{abstract}
Drosophila has made many contributions to our understanding of cancer genes and mechanisms that have subsequently been validated in mammals. Despite anatomical differences between fly and human eyes, flies offer a tractable genetic model in which to dissect the functional importance of genetic lesions found to be affected in human ocular tumors. Here, we discuss different approaches for using Drosophila as a model for ocular cancer and how studies on ocular cancer genes in flies have begun to reveal potential strategies for therapeutic intervention. We also discuss recent developments in the use of Drosophila for drug discovery, which is coming to the fore as Drosophila models are becoming tailored to study tumor types found in the clinic.

(c) 2015 S. Karger AG, Basel
\end{abstract}

\section{Why Use Drosophila as a Cancer Model?}

By combining a century of genetic research resulting in a vast array of powerful genetic tools with modern cutting-edge technologies, Drosophila offers unparalleled opportunities to elucidate complex interactions between genes, cells and tissues [1, 2]. In recent years, Drosophila has been increasingly utilized as a model organism for cancer research after work in cancer cell lines had failed to reliably predict clinical relevance [3] and expensive mammalian models had struggled to provide a sufficiently sophisticated panel of genetic tools to fully capture the intricacy of tumorigenesis and metastasis. Although flies do not normally develop cancer because of their limited life span, many biological processes related to tumorigenesis 
Ocular Oncology

and Pathology

Bennett et al.: Drosophila as a Potential Model for Ocular Tumors

and cancer progression are well conserved in flies, and the disruption or ectopic activation of cancer-related genes can lead to the development of several classic hallmarks of cancer, including genome instability, metabolic reprogramming, evasion of apoptosis, sustained proliferation, resisting cell death and invasive cell migration [4, 5]. Furthermore, studies in flies have yielded important conceptual insights into epithelial cancer development and progression, including cell competition, apoptosis-induced compensatory proliferation and oncogenic cooperation [6].

One of the key advantages of Drosophila is its relatively streamlined genome, which facilitates the conduct of large-scale genetic screens with comparative ease. The low level of redundancy means that hits are likely to provide insight into the gene function, while the high level of homology to 75\% of human disease-causing genes [7] means that Drosophila screens are often directly applicable to higher organisms, including humans. Indeed, such screens have identified many important and conserved cellular regulators that were later shown to be involved in tumor formation in humans, such as Notch (N), Hedgehog (Hh) and Salvador/ Warts/Hippo [8]. Since nearly all of the genes implicated in the growth control from studies of human cancer are conserved in Drosophila, candidate genes identified in human cancers can be extensively studied in flies, where genes can be manipulated with unparalleled precision and the in vivo setting additionally enables studies to assess the role of the microenvironment in tumor development and progression. Furthermore, Drosophila has shown potential as a screening model for novel therapeutic compounds, putting it at the translational interface between basic science and clinical medicine [8].

How good a model is the Drosophila eye for ocular tumors? As with all cancer models, there is always the question of how closely the model replicates the specific cancer type. Obvious anatomical differences between fly eyes and human eyes, with the structure of the photosensitive organ (compound insect eye versus the camera-style human eye) being the most notable, naturally limit how directly applicable findings in flies are to specific cell types in human eyes. Importantly, however, numerous genes involved in eye specification (e.g. ey, toy, so and eya) or in orchestrating the proper temporal and spatial organization of the eye components (e.g. hh and ato) are highly conserved in both flies and humans, and mutations result in retinal defects in both systems alike $[9,10]$. Drosophila therefore offers a valuable genetic model in which to test interactions between cancer-related genes found to drive the development or progression of ocular tumors in humans.

\section{Using the Drosophila Toolkit for Gene Discovery}

Targeted overexpression or knockdown of any number of candidate genes is the breadand-butter methodology utilized by fly geneticists (fig. 1a, b). The targeting techniques are becoming increasingly sophisticated, allowing genes to be misexpressed or knocked down in individual cells, clones of cells or specific tissues at different developmental time points and in different genetic backgrounds [11]. Manipulated cells can be readily labeled with a fluorescent protein, facilitating the analysis of the resultant phenotypes and cellular behaviors such as invasion and metastasis. Clonal analysis (fig. 1b) enables the study of the effects of multiple genetic alterations on populations of cells alongside phenotypically normal cells, recapitulating the events that take place during the growth and spread of cancerous cells in otherwise healthy tissues and organs in humans. It can also inform us about the role of tumor

microenvironments. Sophisticated functional and complementation analyses can be carried out by combining different knockdown or expression constructs, which may be wild type or carry site-directed mutations of interest, with loss-of-function mutants within the same clonal patch. 
Although such analyses can be carried out in a multitude of tissues, the Drosophila eye in particular has attracted much attention because genetic manipulations in this nonessential tissue tend to give rise to viable animals displaying visible and easy-to-score phenotypes. For example, the Drosophila eye has been used to identify pathways required for neoplastic transformation and metastasis in situ. One widely used model utilizes constitutively active Ras $\left(\operatorname{Ras}^{V 12}\right)$ targeted to the developing eye in larvae. $\operatorname{Ras}^{V 12}$ expression results in benign hyperplastic tumors that can be readily used to screen for genetic modifiers required for neoplasia and metastasis (fig. 1c). Studies in this system revealed the critical role of the cell polarity genes scrib, lgl and $\mathrm{dlg}$ in inhibiting tumor progression and metastasis $[12,13]$. In particular, cells lacking scrib and concurrently expressing Ras ${ }^{V 12}$ acquire invasive properties, and affected animals display distant secondary foci of tumorous growths. Genetic

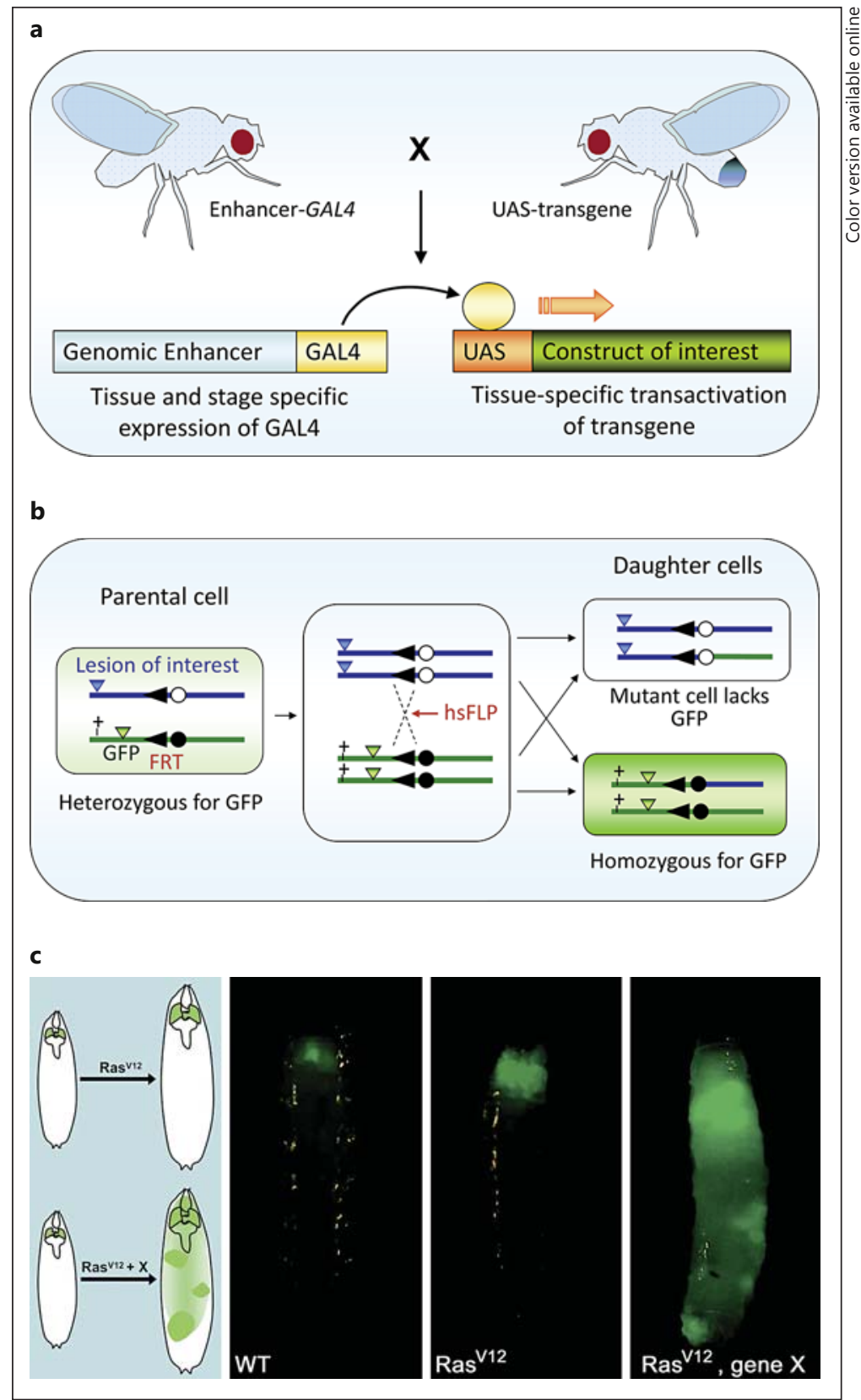

(For legend see next page.) 
analysis has further revealed the role of JNK activation, interclonal cooperation, extracellular matrix remodeling and the immune system for invasion and metastasis in this model (reviewed in Miles et al. [14]). Fundamental insights, such as these, into our understanding of epithelial cancer biology are likely to help guide studies of cancer in more advanced model organisms, including mammals. Indeed, mislocalization or downregulation of Dlg1, Scrib and Lgl1 have been correlated with early dysplastic stages of ocular adenocarcinoma in a mouse model [15].

The strength of Drosophila as an organism of choice for sophisticated genetic screens is further demonstrated by the identification and characterization of a remarkable gain-offunction mutant, eyeful, which was identified as a modifier of the eye overgrowth phenotype resulting from the overexpression of the Notch ligand encoded by Delta [16]. As well as displaying further eye enlargement, flies overexpressing Delta and concurrently carrying the eyeful mutation in the developing eye were found to have ectopic eye tissue throughout the body that originated from the dissemination of transformed cells from the developing eye. Intriguingly, further analysis revealed that the eyeful mutation resulted in the hypermethylation and inhibition of the tumor suppressor gene Retinoblastoma, demonstrating the significance of epigenetic modifications in neoplastic transformation and metastasis [16].

\section{Investigating Ocular Cancer Genes in Drosophila}

Drosophila is increasingly being used to generate specific alterations in conserved tumor suppressors or oncogenes in an attempt to replicate pathway-specific modes of tumorigenesis or metastasis found in different tumor types. These models can then be interrogated, e.g. using forward genetic screens, to devise ways to specifically affect the growth, survival or dissemination of resulting tumor cells. This approach may be of particular relevance to relatively rare cancer types that require tissue-specific or less commonly utilized oncogenic drivers that may be overlooked in forward genetic screens. In the following section, we discuss the insights that studies on the retinoblastoma tumor suppressor gene in flies have

Fig. 1. Utilizing the genetic toolkit in Drosophila for cancer studies. The GAL4/UAS expression system [65] (a) and the FLP/FRT system [66] (b) are two of the most commonly used tools to manipulate gene function in Drosophila. a The GAL4/UAS bipartite expression system allows flexible overexpression or knockdown of a gene of interest in different tissues or stages of development. Flies carrying one of many available GAL4 lines are crossed to flies carrying the gene of interest under the control of the UAS element. Binding of GAL4 to the UAS element in the progeny drives the expression in the pattern of the GAL4 line. Publicly available genome-wide RNA interference and overexpression UAS libraries $[67,68]$ have broadened the utility of this approach. Temperature-sensitive alleles of GAL80, a repressor of GAL4-mediated gene expression, can also be employed in this system for further temporal control of expression (not shown). b The Flp/FRT system can be used to generate clones of mutant cells in otherwise normal tissues. Expression of the Flp gene, for example under the control of a heat shock (hs) promoter, results in recombination between two FRT (Flp recombination target) sites on sister chromatids. One of the resulting daughter cells is consequently homozygous mutant for the gene of interest and is negatively labeled by the absence of GFP, whereas GFP expression labels both the parental cell and the other daughter cell, which are heterozygous and homozygous wild type for the gene of interest, respectively. This system can be coupled with GAL80 to positively label mutant cells lacking the repressor (not shown). c Combining the approaches outlined in $\mathbf{a}$ and $\mathbf{b}$, it is possible to generate clones of cells ectopically expressing an activated oncogene whilst simultaneously harboring additional mutations that affect the properties of the resulting tumors (see Pagliarini and Xu [12] for details). For instance, cells overexpressing Ras $^{V 12}$ in the developing eye lead to localized non-invasive tumors. The presence of additional metastasis-inducing factors (e.g. gene $\mathrm{X}$ ) drives the formation of secondary tumors visualized by the presence of GFP in other parts of the larva. 
Bennett et al.: Drosophila as a Potential Model for Ocular Tumors

made towards potential treatments of the corresponding disease and explore the potential for developing models of uveal melanoma, the most common malignant tumor of the eye in adults, based on what is known about the underlying genetic drivers.

\section{RB1 and Retinoblastoma}

Retinoblastoma, the most common malignant tumor of the eye in children, is an aggressive neoplasm that develops from immature cells of the retina following biallelic loss of the RB1 gene $[17,18]$. Like RB1, the Drosophila ortholog rbf1 is best known for the regulation of the G1/S transition via the repression of E2F-dependent transcription [19]. Mutations in $r b f 1$ have only a modest effect on eye development and are not sufficient to drive tumor formation in Drosophila. By investigating context-dependent effects, it has been found that both $r b f 1$ and RB1 cooperate with the hippo tumor suppressor pathway in cell proliferation control and cell specification. Cells that are double mutant for rbf1 and hippo dedifferentiate from a neuronal state and become uncommitted eye-specific cells with an increased potential to contribute to tumor growth [20]. It was subsequently shown that Yki, a transcriptional coactivator that is inactivated by Hippo signaling in flies, requires the transcription factor E2F to transcribe genes necessary to bypass exit from the cell cycle [21]. Similarly, the Hippo pathway and the RB1-mediated regulation of the G1/S transition in human cells are required for RB1-mediated repression of E2F target genes and consequent RB1-induced inhibition of cell proliferation [22].

A further constraint on tumor development is that $r b f 1$ mutant cells are sensitized to undergo apoptosis, which can be triggered for example by signaling from the cellular microenvironment [23] or by further genetic insults to the defective cells [24]. Using clonal genetic screens in the fly eye, loss-of-function mutations in the Tsc2 tumor suppressor [24] or a highly conserved peptidyl prolyl isomerase [25] were independently found to eliminate cells lacking $r b f 1$ but allow wild-type cells to survive. It was subsequently found that inactivation of human Tsc2 in cancer cells inhibited the growth of RB1 mutant cells and induced cell death under stress conditions [24], suggesting potential therapeutic strategies for treating cancers in which RB1 has been inactivated. Importantly, the confirmation of synthetic lethality in a cancer cell line clearly illustrates the power of Drosophila as a discovery tool.

\section{Uveal Melanoma Cancer Genes}

Whereas retinoblastoma is largely considered to be a single-gene disease, in uveal melanoma, several genetic and epigenetic lesions have been variously associated with tumor development or progression [26]. As illustrated above, multigenic models of tumorigenesis can be readily generated in the fly. Activated oncogenes can be readily expressed ectopically; however, modeling the effects of the loss of human tumor suppressor genes is limited by the requirement for the presence and expression of the relevant homologs in the fly. Importantly, almost all of the genes implicated in uveal melanoma are conserved in Drosophila (table 1), including ubiquitous oncogenes or tumor suppressors, such as IGFR1, B-RAF and PTEN, which play conserved roles in growth and proliferation control in all metazoans, as well as highly conserved tissue-specific factors, such as G protein $\alpha_{q}$ subunits GNAQ/GNA11 [27], which in Drosophila is required for the termination of phototransduction and prevents retinal degeneration [28]. The insult most closely associated with metastasis of uveal melanoma cells is somatic loss-of-function mutations in the BRCA1-associated protein 1(BAP1) tumor suppressor, which have been reported in nearly $50 \%$ of primary uveal melanomas and $84 \%$ of metastasizing tumors $[29,30]$. Both human BAP1 and the Drosophila counterpart encoded by calypso act as the catalytic subunits of a Polycomb repressive deubiquitinase (PR-DUB) complex, which remove ubiquitin from histone H2A in nucleosomes to repress Hox and other genes [31]. This is particularly interesting given the well-established role of certain Polycomb Group (PcG) genes as tumor suppressors in the Drosophila eye, including Sex combs extra (Sce, an E3 ligase 
Table 1. Uveal melanoma cancer genes and their counterparts in Drosophila

\begin{tabular}{|c|c|c|c|c|}
\hline $\begin{array}{l}\text { Associated human } \\
\text { gene }\end{array}$ & Contribution to uveal melanoma & Frequency & $\begin{array}{l}\text { Drosophila } \\
\text { orthologue }\end{array}$ & Effect in Drosophila \\
\hline \multicolumn{5}{|l|}{ Tumor suppressors } \\
\hline$B A P 1$ & $\begin{array}{l}\text { Mutational inactivation of BAP1 } \\
\text { implicated in uveal melanoma } \\
\text { metastasis }[29,30]\end{array}$ & $\begin{array}{l}\text { Inactivating somatic mutations in up } \\
\text { to } 84 \% \text { of tumors }\end{array}$ & calypso & Control of cellular differentiation \\
\hline$\overline{P T E N}$ & $\begin{array}{l}\text { Submicroscopic deletions lead to } \\
\text { loss of PTEN expression in uveal } \\
\text { melanoma [39] }\end{array}$ & $\begin{array}{l}\text { Mutations in the PTEN coding region } \\
\text { identified in } 11.4 \% \text { of tumors; up to } \\
76.3 \% \text { of tumors with loss of } \\
\text { heterozygosity of at least one PTEN } \\
\text { marker }\end{array}$ & PTEN & $\begin{array}{l}\text { PTEN mutants exhibit eye } \\
\text { overgrowth, whereas PTEN } \\
\text { overexpression inhibits cell } \\
\text { proliferation and promotes cell death } \\
\text { during eye development [40] }\end{array}$ \\
\hline$\overline{p 53}$ & $\begin{array}{l}\text { Altered expression in uveal } \\
\text { melanomas following plaque } \\
\text { radiotherapy, with elevated p53 } \\
\text { levels [41] }\end{array}$ & $\begin{array}{l}\text { Strong p53 staining observed in } 50 \% \\
\text { of eyes containing posterior uveal } \\
\text { melanomas }\end{array}$ & $p 53$ & $\begin{array}{l}\text { Ectopic expression in the eye disc } \\
\text { causes cell death and leads to a rough } \\
\text { eye phenotype [42] }\end{array}$ \\
\hline$\overline{S F 3 B 1}$ & $\begin{array}{l}\text { Mutations in a distinct molecular } \\
\text { subset of uveal melanomas [43] }\end{array}$ & Mutations in $18.6 \%$ of tumors & CG2807-PA & No phenotypic data \\
\hline \multicolumn{5}{|c|}{ Potential diagnostic markers } \\
\hline$M C 1 R$ & $\begin{array}{l}\text { Highly overexpressed in uveal } \\
\text { melanoma [44] }\end{array}$ & $\begin{array}{l}\text { Detected in } 95 \% \text { of tested melanoma } \\
\text { tissues }\end{array}$ & $\begin{array}{l}\text { No clear } \\
\text { orthologue } \\
\text { identified }\end{array}$ & \\
\hline $\begin{array}{l}\text { SSR2, SSTR3 and } \\
\text { SSTR5 }\end{array}$ & $\begin{array}{l}\text { Expressed in human uveal } \\
\text { melanomas; better prognosis for } \\
\text { patients with high levels of SSR2 in } \\
\text { melanoma tissue [45] }\end{array}$ & $\begin{array}{l}\text { Immunohistochemical staining } \\
\text { positive for SSR2 in all uveal } \\
\text { melanomas, whilst SSR3 was found in } \\
29 \% \text { and SSR5 in } 58 \% \text { of tumors }\end{array}$ & AlCR2 & $\begin{array}{l}\text { AlCR2 is closest to SSR2; no data for } \\
\text { the effect on the eye }\end{array}$ \\
\hline \multicolumn{5}{|l|}{ Proto-oncogenes } \\
\hline$G N A Q$ and $G N A 11$ & $\begin{array}{l}\text { Constitutively active in uveal } \\
\text { melanoma }[27,46]\end{array}$ & $\begin{array}{l}\text { Activating mutations affecting GNA11 } \\
\text { in up to } 49 \% \text { of primary uveal } \\
\text { melanomas and in } 45 \% \text { of uveal } \\
\text { melanomas for GNAQ }\end{array}$ & Gaq & $\begin{array}{l}\text { Loss leads to retinal degeneration } \\
\text { [28] }\end{array}$ \\
\hline$\overline{M Y C}$ & $\begin{array}{l}\text { Amplification of the c-myc } \\
\text { oncogene detected in } 43 \% \text { of uveal } \\
\text { melanomas [47] }\end{array}$ & $\begin{array}{l}70 \% \text { of uveal melanomas with extra } \\
\text { copies of c-myc }\end{array}$ & diminutive & $\begin{array}{l}\text { Myc overexpression in the eye } \\
\text { induces both growth and apoptosis, } \\
\text { yielding large rough eyes [48] }\end{array}$ \\
\hline$\overline{C C N D 1}$ & $\begin{array}{l}\text { Cyclin D1 protein expression was } \\
\text { observed in } 65 \% \text { of uveal } \\
\text { melanomas [49] and is associated } \\
\text { with more aggressive disease [50] }\end{array}$ & $\begin{array}{l}\text { Expression observed in } 65 \% \text { of uveal } \\
\text { melanomas }\end{array}$ & Cyclin D & $\begin{array}{l}\text { Clonal expression of CycD-Cdk4 } \\
\text { promotes cellular hypertrophy in } \\
\text { post-mitotic cells of differentiating } \\
\text { eyes [51] }\end{array}$ \\
\hline$\overline{D D E F 1}$ & $\begin{array}{l}\text { DDEF1 is commonly overexpressed } \\
\text { in high-grade uveal melanomas } \\
\text { [52] }\end{array}$ & $\begin{array}{l}\text { Elevated expression in high-grade } \\
\text { (class 2) tumors, corresponding to } \\
50 \% \text { of uveal melanoma patients more } \\
\text { likely to die of metastatic disease }\end{array}$ & Asap1 & No phenotypic data are available \\
\hline$\overline{N B S 1}$ & $\begin{array}{l}\text { High expression of Nbs1 associated } \\
\text { with increased metastatic death in } \\
\text { uveal melanoma patients [53] }\end{array}$ & $\begin{array}{l}\text { Elevated expression in high-grade } \\
\text { (class 2) tumors, corresponding to } \\
50 \% \text { of uveal melanoma patients more } \\
\text { likely to die of metastatic disease }\end{array}$ & $n b s$ & $\begin{array}{l}\text { Null mutant flies die as pharate adults } \\
\text { with rough eyes [54] }\end{array}$ \\
\hline$\overline{I G F 1 R}$ & $\begin{array}{l}\text { High expression associated with } \\
\text { metastases of primary uveal } \\
\text { melanomas [55] }\end{array}$ & $\begin{array}{l}\text { High IGF1R expression in } 50 \% \text { of } \\
\text { patients who died following } \\
\text { metastasis but in only } 25 \% \text { of patients } \\
\text { who survived } 15 \text { years }\end{array}$ & $\operatorname{InR}$ & $\begin{array}{l}\text { Increased activity leads to overgrowth } \\
\text { of the eye, reduced activity leads to } \\
\text { reduced eye growth [56] }\end{array}$ \\
\hline$\overline{J a g 2}$ & $\begin{array}{l}\text { May promote Notch activity, } \\
\text { growth and metastasis in uveal } \\
\text { melanoma [57] }\end{array}$ & $\begin{array}{l}\text { Elevated expression in high-grade } \\
\text { (class 2) tumors, corresponding to } \\
50 \% \text { of uveal melanoma patients more } \\
\text { likely to die of metastatic disease }\end{array}$ & Serrate & $\begin{array}{l}\text { Loss of function has no discernible } \\
\text { effect on eye development [58] but is } \\
\text { required for cell survival with Lobe } \\
\text { during early eye development [59] }\end{array}$ \\
\hline$\overline{B-R A F}$ & $\begin{array}{l}\text { Low prevalence of mutations but } \\
\text { frequent downstream activation of } \\
\text { the MAPK pathway associated with } \\
\text { uveal melanoma [60-62] }\end{array}$ & $\begin{array}{l}\text { Rare; mutations detected in } 14.3 \% \text { of } \\
\text { uveal melanoma cell lines and primary } \\
\text { specimens }\end{array}$ & phl & $\begin{array}{l}\text { Rough eye phenotype due to loss of } \\
\text { photoreceptor cells [63]; } \\
\text { photoreceptors fail to differentiate in } \\
\text { mutant somatic clones of the larval } \\
\text { eye disc [64] }\end{array}$ \\
\hline
\end{tabular}

$M C 1 R=$ Melanocortin 1 receptor; $A I C R 2$ = allatostatin C receptor 1; Gaq = G protein $\alpha$ q subunit; IGF1R = insulin-like growth factor 1 receptor; InR = insulin-like receptor; $p h l=$ pole hole .

required for $\mathrm{H} 2 \mathrm{~A}$ monoubiquitylation), which operates synergistically with the PR-DUB complex to transcriptionally repress a subset of PcG target genes [32, 33]. Armed with the knowledge of some of the genetic events driving uveal melanoma [26] and given the conservation of the affected genes in flies, it will be possible to begin to devise Drosophila models with which to help determine the key players in uveal melanoma development and progression. 


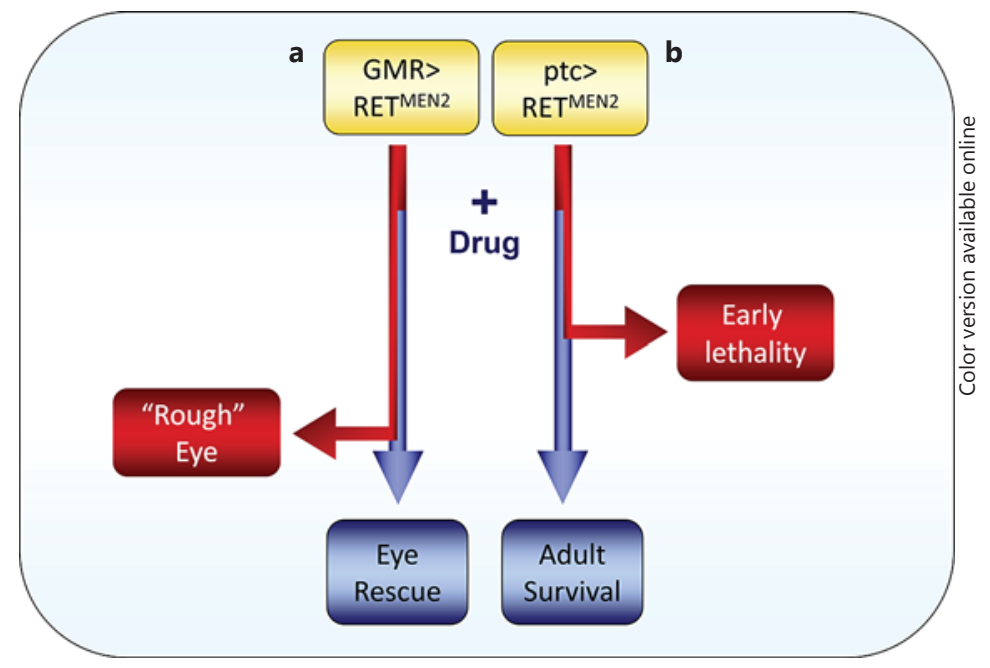

Fig. 2. Strategies for testing the ability of chemical inhibitors to suppress the effects of RET ${ }^{\mathrm{MEN} 2}$ overexpression in Drosophila. a Eye-specific expression: ectopic overexpression of $R E T^{M E N 2}$ under the control of the GMR promoter results in a fully penetrant rough eye phenotype in adults (red lines). Flies fed with vandetanib (ZD6474) strongly rescue defective eye development (blue line) [35]. b Expression in developing epithelia (wing, eye and leg) and other tissues: ectopic expression of UAS-RET ${ }^{\mathrm{MEN} 2}$ under the control of ptc-GAL4 results in lethality early in development (red line). This assay was used to screen a library of polypharmacological compounds capable of restoring viability (blue line). Further chemical refinement of initial hits identified a compound, AD80, with optimal efficacy and toxicity compared to analogs [37]. Colors refer to the online version only.

\section{Future Perspectives}

Future efforts to develop Drosophila strains that are specifically modeled on human data will ensure that insights can be more quickly taken back into mammals or cancer cell lines for validation and ultimate translation into clinical practice. With respect to translational potential, Drosophila has begun to emerge as a time and cost-efficient model for whole-animal drug testing to find suitable compounds capable of targeting cancer signaling in a multicellular context. A particularly successful example of the utility of Drosophila for drug development has come from studies of activated forms of the RET (rearranged during transfection) proto-oncogene, which are associated with several types of cancers, including type 2 multiple endocrine neoplasia (MEN2), an inherited condition that can result in the development of cancers such as medullary thyroid carcinoma (fig. 2). Ectopic expression of oncogenic RET $\left(R E T^{M E N 2}\right)$ in the developing fly eye results in overproliferation, cell fate defects and cell death, leading to the formation of visibly 'rough' adult eyes [34]. Using this simple assay, flies were fed ZD6474 (vandetanib) to test whether this compound, which had previously been shown to inhibit RET, was capable of modulating $R E T^{M E N 2}$ function in the whole organism when administered orally [35]. Notably, ZD6474 suppressed the $R E T^{M E N 2}$-mediated phenotypes at doses much lower than those required to cause toxicity to the animal. Following validation in flies, this compound subsequently passed clinical trials for the use in treating medullary thyroid carcinoma [36] and became the first drug to be approved by the FDA for the treatment of late-stage medullary thyroid cancer in adult patients who might be considered ineligible for surgery due to metastasis. This success has recently prompted further efforts to better understand the pathways responsible for drug efficacy and dose-limiting toxicity in the Drosophila $\mathrm{RET}^{\mathrm{MEN} 2}$ model as well as to develop new compounds with improved therapeutic 
indices [37] (fig. 2b). Semi-automated methods for high-throughput screening are also being trialed to screen chemical compounds in larvae. A recent screen for suppressors of Ras ${ }^{V 12}$ $\mathrm{scrib}^{-/-}$tumor overgrowth in the developing eye identified clinically active drugs with known activity against human tumor cells that are similarly effective in flies [38]. These studies illustrate how models of cancer involving multiple genetic alterations in flies can serve as a starting point for pharmacological interrogation and how Drosophila can provide an important function in preselecting the most useful compounds prior to testing in more expensive mammalian models.

\section{Conclusion}

There is a long tradition of using Drosophila to identify universal regulators of basic cellular processes such as proliferation, differentiation and death. As more genetic data from clinical samples become available, Drosophila models offer the potential to recapitulate the properties of ocular tumors with increasing accuracy and therefore applicability. Aside from providing valuable mechanistic insight, tailored cancer models are increasingly being seen to have promise in drug discovery efforts, where they can help to bridge the gap from bench to bedside.

\section{Acknowledgements}

D.B. is supported by grants from CRUK and NWCR. E.L. is an Academic Clinical Fellow in Clinical Genetics. N.C. is supported by the NWCR.

\section{References}

1 Matthews KA, Kaufman TC, Gelbart WM: Research resources for Drosophila: the expanding universe. Nat Rev Genet 2005;6:179-193.

-2 Venken KJ, Bellen HJ: Emerging technologies for gene manipulation in Drosophila melanogaster. Nat Rev Genet 2005;6:167-178.

-3 Gillet JP, Varma S, Gottesman MM: The clinical relevance of cancer cell lines. J Natl Cancer Inst 2012;105:452458.

4 Hanahan D, Weinberg RA: The hallmarks of cancer. Cell 2000;100:57-70.

5 Hanahan D, Weinberg RA: Hallmarks of cancer: the next generation. Cell 2011;144:646-674.

6 Vidal M, Cagan RL: Drosophila models for cancer research. Curr Opin Genet Dev 2006;16:10-16.

7 Reiter LT, Potocki L, Chien S, Gribskov M, Bier E: A systematic analysis of human disease-associated gene sequences in Drosophila melanogaster. Genome Res 2001;11:1114-1125.

-8 Gonzalez C: Drosophila melanogaster: a model and a tool to investigate malignancy and identify new therapeutics. Nat Rev Cancer 2013;13:172-183.

$\checkmark 9$ Jarman AP: Developmental genetics: vertebrates and insects see eye to eye. Curr Biol 2000;10:R857-R859.

10 Kumar JP: Signalling pathways in Drosophila and vertebrate retinal development. Nat Rev Genet 2001;2: 846-857.

11 Venken KJ, Bellen HJ: Genome-wide manipulations of Drosophila melanogaster with transposons, Flp recombinase, and PhiC31 integrase. Methods Mol Biol 2012;859:203-228.

12 Pagliarini RA, Xu T: A genetic screen in Drosophila for metastatic behavior. Science 2003;302:1227-1231.

13 Brumby AM, Richardson HE: scribble mutants cooperate with oncogenic Ras or Notch to cause neoplastic overgrowth in Drosophila. EMBO J 2003;22:5769-5779.

$\checkmark 14$ Miles WO, Dyson NJ, Walker JA: Modeling tumor invasion and metastasis in Drosophila. Dis Model Mech 2011; 4:753-761.

15 Vieira V, de la Houssaye G, Lacassagne E, Dufier JL, Jais JP, Beermann F, Menasche M, Abitbol M: Differential regulation of Dlg1, Scrib, and Lgl1 expression in a transgenic mouse model of ocular cancer. Mol Vis 2008;14: 2390-2403.

-16 Ferres-Marco D, Gutierrez-Garcia I, Vallejo DM, Bolivar J, Gutierrez-Avino FJ, Dominguez M: Epigenetic silencers and Notch collaborate to promote malignant tumours by Rb silencing. Nature 2006;439:430-436. 
Bennett et al.: Drosophila as a Potential Model for Ocular Tumors

17 Lohmann DR, Brandt B, Hopping W, Passarge E, Horsthemke B: The spectrum of RB1 germ-line mutations in hereditary retinoblastoma. Am J Hum Genet 1996;58:940-949.

18 Zhang J, Benavente CA, McEvoy J, Flores-Otero J, Ding L, Chen X, Ulyanov A, Wu G, Wilson M, Wang J, Brennan R, Rusch M, Manning AL, Ma J, Easton J, Shurtleff S, Mullighan C, Pounds S, Mukatira S, Gupta P, Neale G, Zhao D, Lu C, Fulton RS, Fulton LL, Hong X, Dooling DJ, Ochoa K, Naeve C, Dyson NJ, Mardis ER, Bahrami A, Ellison D, Wilson RK, Downing JR, Dyer MA: A novel retinoblastoma therapy from genomic and epigenetic analyses. Nature 2012;481:329-334.

19 Du W, Vidal M, Xie JE, Dyson N: RBF, a novel RB-related gene that regulates E2F activity and interacts with cyclin E in Drosophila. Genes Dev 1996;10:1206-1218.

20 Nicolay BN, Bayarmagnai B, Moon NS, Benevolenskaya EV, Frolov MV: Combined inactivation of pRB and hippo pathways induces dedifferentiation in the Drosophila retina. PLoS Genet 2010;6:e1000918.

-21 Nicolay BN, Bayarmagnai B, Islam AB, Lopez-Bigas N, Frolov MV: Cooperation between dE2F1 and Yki/Sd defines a distinct transcriptional program necessary to bypass cell cycle exit. Genes Dev 2011;25:323-335.

22 Tschop K, Conery AR, Litovchick L, Decaprio JA, Settleman J, Harlow E, Dyson N: A kinase shRNA screen links LATS2 and the pRB tumor suppressor. Genes Dev 2011;25:814-830.

23 Moon NS, Di Stefano L, Dyson N: A gradient of epidermal growth factor receptor signaling determines the sensitivity of rbf1 mutant cells to E2F-dependent apoptosis. Mol Cell Biol 2006;26:7601-7615.

24 Li B, Gordon GM, Du CH, Xu J, Du W: Specific killing of Rb mutant cancer cells by inactivating TSC2. Cancer Cell 2010;17:469-480.

-25 Edgar KA, Belvin M, Parks AL, Whittaker K, Mahoney MB, Nicoll M, Park CC, Winter CG, Chen F, Lickteig K, Ahmad F, Esengil H, Lorenzi MV, Norton A, Rupnow BA, Shayesteh L, Tabios M, Young LM, Carroll PM, Kopczynski C, Plowman GD, Friedman LS, Francis-Lang HL: Synthetic lethality of retinoblastoma mutant cells in the Drosophila eye by mutation of a novel peptidyl prolyl isomerase gene. Genetics 2005;170:161-171.

-26 Coupland SE, Lake SL, Zeschnigk M, Damato BE: Molecular pathology of uveal melanoma. Eye (Lond) 2013;27: 230-242.

27 Van Raamsdonk CD, Griewank KG, Crosby MB, Garrido MC, Vemula S, Wiesner T, Obenauf AC, Wackernagel W, Green G, Bouvier N, Sozen MM, Baimukanova G, Roy R, Heguy A, Dolgalev I, Khanin R, Busam K, Speicher MR, O’Brien J, Bastian BC: Mutations in GNA11 in uveal melanoma. N Engl J Med 2010;363:2191-2199.

$28 \mathrm{Hu}$ W, Wan D, Yu X, Cao J, Guo P, Li HS, Han J: Protein Gq modulates termination of phototransduction and prevents retinal degeneration. J Biol Chem 2012;287:13911-13918.

29 Abdel-Rahman MH, Pilarski R, Cebulla CM, Massengill JB, Christopher BN, Boru G, Hovland P, Davidorf FH: Germline BAP1 mutation predisposes to uveal melanoma, lung adenocarcinoma, meningioma, and other cancers. J Med Genet 2011;48:856-859.

-30 Harbour JW, Onken MD, Roberson ED, Duan S, Cao L, Worley LA, Council ML, Matatall KA, Helms C, Bowcock AM: Frequent mutation of BAP1 in metastasizing uveal melanomas. Science 2010;330:1410-1413.

31 Scheuermann JC, de Ayala Alonso AG, Oktaba K, Ly-Hartig N, McGinty RK, Fraterman S, Wilm M, Muir TW, Muller J: Histone H2A deubiquitinase activity of the Polycomb repressive complex PR-DUB. Nature 2010;465:243-247.

32 Gutierrez L, Oktaba K, Scheuermann JC, Gambetta MC, Ly-Hartig N, Muller J: The role of the histone H2A ubiquitinase Sce in Polycomb repression. Development 2012;139:117-127.

-33 Classen AK, Bunker BD, Harvey KF, Vaccari T, Bilder D: A tumor suppressor activity of Drosophila Polycomb genes mediated by JAK-STAT signaling. Nat Genet 2009;41:1150-1155.

34 Read RD, Goodfellow PJ, Mardis ER, Novak N, Armstrong JR, Cagan RL: A Drosophila model of multiple endocrine neoplasia type 2. Genetics 2005;171:1057-1081.

-35 Vidal M, Wells S, Ryan A, Cagan R: ZD6474 suppresses oncogenic RET isoforms in a Drosophila model for type 2 multiple endocrine neoplasia syndromes and papillary thyroid carcinoma. Cancer Res 2005;65:3538-3541.

-36 Wells SA Jr, Robinson BG, Gagel RF, Dralle H, Fagin JA, Santoro M, Baudin E, Elisei R, Jarzab B, Vasselli JR, Read J, Langmuir P, Ryan AJ, Schlumberger MJ: Vandetanib in patients with locally advanced or metastatic medullary thyroid cancer: a randomized, double-blind phase III trial. J Clin Oncol 2012;30:134-141.

37 Dar AC, Das TK, Shokat KM, Cagan RL: Chemical genetic discovery of targets and anti-targets for cancer polypharmacology. Nature 2012;486:80-84.

-38 Willoughby LF, Schlosser T, Manning SA, Parisot JP, Street IP, Richardson HE, Humbert PO, Brumby AM: An in vivo large-scale chemical screening platform using Drosophila for anti-cancer drug discovery. Dis Model Mech 2013;6:521-529.

-39 Abdel-Rahman MH, Yang Y, Zhou XP, Craig EL, Davidorf FH, Eng C: High frequency of submicroscopic hemizygous deletion is a major mechanism of loss of expression of PTEN in uveal melanoma. J Clin Oncol 2006;24: 288-295.

40 Huang H, Potter CJ, Tao W, Li DM, Brogiolo W, Hafen E, Sun H, Xu T: PTEN affects cell size, cell proliferation and apoptosis during Drosophila eye development. Development 1999;126:5365-5372.

41 Brantley MA Jr, Worley L, Harbour JW: Altered expression of Rb and p53 in uveal melanomas following plaque radiotherapy. Am J Ophthalmol 2002;133:242-248.

42 Yamaguchi M, Hirose F, Inoue YH, Shiraki M, Hayashi Y, Nishi Y, Matsukage A: Ectopic expression of human p53 inhibits entry into S phase and induces apoptosis in the Drosophila eye imaginal disc. Oncogene 1999;18: 6767-6775.

43 Harbour JW, Roberson ED, Anbunathan H, Onken MD, Worley LA, Bowcock AM: Recurrent mutations at codon 625 of the splicing factor SF3B1 in uveal melanoma. Nat Genet 2013;45:133-135. 
Ocular Oncology

and Pathology
Ocul Oncol Pathol 2015;1:190-199

DOI: $10.1159 / 000370155$
(C) 2015 S. Karger AG, Base www.karger.com/oop

Bennett et al.: Drosophila as a Potential Model for Ocular Tumors

44 Lopez MN, Pereda C, Ramirez M, Mendoza-Naranjo A, Serrano A, Ferreira A, Poblete R, Kalergis AM, Kiessling $\mathrm{R}$, Salazar-Onfray F: Melanocortin 1 receptor is expressed by uveal malignant melanoma and can be considered a new target for diagnosis and immunotherapy. Invest Ophthalmol Vis Sci 2007;48:1219-1227.

-45 Ardjomand N, Ardjomand N, Schaffler G, Radner H, El-Shabrawi Y: Expression of somatostatin receptors in uveal melanomas. Invest Ophthalmol Vis Sci 2003;44:980-987.

46 Onken MD, Worley LA, Long MD, Duan S, Council ML, Bowcock AM, Harbour JW: Oncogenic mutations in GNAQ occur early in uveal melanoma. Invest Ophthalmol Vis Sci 2008;49:5230-5234.

47 Parrella P, Caballero OL, Sidransky D, Merbs SL: Detection of c-myc amplification in uveal melanoma by fluorescent in situ hybridization. Invest Ophthalmol Vis Sci 2001;42:1679-1684.

48 Steiger D, Furrer M, Schwinkendorf D, Gallant P: Max-independent functions of Myc in Drosophila melanogaster. Nat Genet 2008;40:1084-1091.

49 Coupland SE, Bechrakis N, Schuler A, Anagnostopoulos I, Hummel M, Bornfeld N, Stein H: Expression patterns of cyclin D1 and related proteins regulating G1-S phase transition in uveal melanoma and retinoblastoma. Br J Ophthalmol 1998;82:961-970.

50 Coupland SE, Anastassiou G, Stang A, Schilling H, Anagnostopoulos I, Bornfeld N, Stein H: The prognostic value of cyclin D1, p53, and MDM2 protein expression in uveal melanoma. J Pathol 2000;191:120-126.

51 Datar SA, Jacobs HW, de la Cruz AF, Lehner CF, Edgar BA: The Drosophila cyclin D-Cdk4 complex promotes cellular growth. EMBO J 2000;19:4543-4554.

-52 Ehlers JP, Worley L, Onken MD, Harbour JW: DDEF1 is located in an amplified region of chromosome 8q and is overexpressed in uveal melanoma. Clin Cancer Res 2005;11:3609-3613.

53 Ehlers JP, Harbour JW: NBS1 expression as a prognostic marker in uveal melanoma. Clin Cancer Res 2005;11: 1849-1853.

54 Oikemus SR, Queiroz-Machado J, Lai K, McGinnis N, Sunkel C, Brodsky MH: Epigenetic telomere protection by Drosophila DNA damage response pathways. PLoS Genet 2006;2:e71.

55 All-Ericsson C, Girnita L, Seregard S, Bartolazzi A, Jager MJ, Larsson O: Insulin-like growth factor-1 receptor in uveal melanoma: a predictor for metastatic disease and a potential therapeutic target. Invest Ophthalmol Vis Sci 2002;43:1-8.

56 Brogiolo W, Stocker H, Ikeya T, Rintelen F, Fernandez R, Hafen E: An evolutionarily conserved function of the Drosophila insulin receptor and insulin-like peptides in growth control. Curr Biol 2001;11:213-221.

-57 Asnaghi L, Handa JT, Merbs SL, Harbour JW, Eberhart CG: A role for Jag2 in promoting uveal melanoma dissemination and growth. Invest Ophthalmol Vis Sci 2013;54:295-306.

58 Baker NE, Yu SY: Proneural function of neurogenic genes in the developing Drosophila eye. Curr Biol 1997; 7: 122-132.

59 Singh A, Shi X, Choi KW: Lobe and Serrate are required for cell survival during early eye development in Drosophila. Development 2006;133:4771-4781.

60 Calipel A, Lefevre G, Pouponnot C, Mouriaux F, Eychene A, Mascarelli F: Mutation of B-Raf in human choroidal melanoma cells mediates cell proliferation and transformation through the MEK/ERK pathway. J Biol Chem 2003;278:42409-42418.

61 Maat W, Kilic E, Luyten GP, de Klein A, Jager MJ, Gruis NA, Van der Velden PA: Pyrophosphorolysis detects B-RAF mutations in primary uveal melanoma. Invest Ophthalmol Vis Sci 2008;49:23-27.

-62 Zuidervaart W, van Nieuwpoort F, Stark M, Dijkman R, Packer L, Borgstein AM, Pavey S, van der Velden P, Out C, Jager MJ, Hayward NK, Gruis NA: Activation of the MAPK pathway is a common event in uveal melanomas although it rarely occurs through mutation of BRAF or RAS. Br J Cancer 2005;92:2032-2038.

63 Lim YM, Tsuda L, Inoue YH, Irie K, Adachi-Yamada T, Hata M, Nishi Y, Matsumoto K, Nishida Y: Dominant mutations of Drosophila MAP kinase kinase and their activities in Drosophila and yeast MAP kinase cascades. Genetics 1997;146:263-273.

64 Yang L, Baker NE: Cell cycle withdrawal, progression, and cell survival regulation by EGFR and its effectors in the differentiating Drosophila eye. Dev Cell 2003;4:359-369.

65 Elliott DA, Brand AH: The GAL4 system: a versatile system for the expression of genes. Methods Mol Biol 2008; 420:79-95.

66 Theodosiou NA, Xu T: Use of FLP/FRT system to study Drosophila development. Methods 1998;14:355-365.

67 Bischof J, Bjorklund M, Furger E, Schertel C, Taipale J, Basler K: A versatile platform for creating a comprehensive UAS-ORFeome library in Drosophila. Development 2013;140:2434-2442.

68 Dietzl G, Chen D, Schnorrer F, Su KC, Barinova Y, Fellner M, Gasser B, Kinsey K, Oppel S, Scheiblauer S, Couto A, Marra V, Keleman K, Dickson BJ: A genome-wide transgenic RNAi library for conditional gene inactivation in Drosophila. Nature 2007;448:151-156. 